\title{
Грамматика Оттепели
}

ПИНСКИЙ А. (РЕД.). (2018). ПОСЛЕ СТАЛИНА: ПОЗДНЕСОВЕТСКАЯ СУБЪЕКТИВНОСТЬ (1953-1985). СПБ.: ИЗД-ВО ЕУСПБ. 454 С. ІSBN 978-5-94380-242-3

\author{
Максим Фетисов \\ Кандидат философских наук, координатор Центра социальной теории \\ и политической антропологии им. Н. Н. Козловой философского факультета \\ Российского государственного гуманитарного университета \\ Адрес: Миусская площадь, д. 6, ГСП-з, Москва, Российская Федерация 125993 \\ E-mail: msfetisov@gmail.com
}

Сборник статей «После Сталина», выпущенный издательством Европейского университета в Санкт-Петербурге, - еще один «кирпичик» в гигантском здании Soviet Studies, уже давно возводимом совместными усилиями и отечественных и зарубежных ученых. Он выпущен по следам конференции «После Сталина: позднесоветская личность 1953-1985», прошедшей в Европейском университете в Санкт-Петербурге в апреле 2014 года. К моменту издания подзаголовок книги претерпел небольшое изменение и звучит теперь так: «Позднесоветская субъективность (1953-1985)». Из того же подзаголовка читатель может сделать справедливый вывод о том, что книга вполне вписывается в «ревизионистский поворот», начавшийся (уже довольно давно) в исследованиях истории советского общества с публикации книг Шейлы Фицпатрик и Стивена Коткина ${ }^{1}$. Необходимость пересмотра подходов к изучению советского начала осознаваться тогда, когда стало понятно, что имеющиеся массивы исторических и социологических данных не укладываются в жесткие рамки концепций «тоталитарного общества», а принятая теоретическая оптика нуждается в серьезном расширении. В отечественную «советологию» ревизионизм проник, как обычно, с запозданием. В 1990-е и 2000-е годы были предприняты попытки пересмотра существовавших в тот момент концептуальных рамок. Так, Олег Хархордин в книге «Обличать и лицемерить» попытался применить фукианский генеалогический инструментарий к советским практикам индивидуализации, а Наталия Козлова еще в середине 1990-х инициировала амбициозный проект исследования советских эгонарративов, поместив их в широкую социально-теоретическую перспективу². Однако эти попытки либо

(С) Фетисов М. С., 2018

( Центр фундаментальной социологии, 2018

DOI: $10.17323 / 1728-192 X-2018-2-373-379$

1. См. посл. издания книг Фицпатрик: Фициатрик Ш. (2008). Сталинские крестьяне: социальная история Советской России в зо-е годы. Деревня / Пер. с англ. Л. Пантиной. М.: РОССПЭН; Фициатрик Ш. (2008). Повседневный сталинизм: социальная история Советской России в зо-е годы. Город / Пер. с англ. Л. Пантиной. М.: РОССПЭН; Kotkin S. (1995). Magnetic Mountain: Stalinism as a Civilization. Berkeley: University of California Press.

2. Хархордин О. (2002). Обличать и лицемерить: генеалогия российской личности. СПб.: Изд-во ЕУСПб. См. также работы Н. Козловой, прежде всего ее последнюю книгу: Козлова Н. Н. (2005). Советские люди: сцены из истории. М.: Европа. 
не получили должного отклика, либо были восприняты как покушение на credo постсоветской интеллигенции ${ }^{3}$. Ситуация начала меняться к середине текущего десятилетия, когда вышло в свет русское издание прорывной книги Алексея Юрчака «Это было навсегда, пока не кончилось» ${ }^{4}$. Последующее появление русскоязычных изданий таких значимых книг, как «Революция от первого лица» Йохена Хелльбека или «Взращивание масс» Дэвида Хоффмана, безусловно, закрепило эти изменения, публикация же книг, подобных рецензируемому изданию, позволяет говорить о том, что «ревизионистский» поворот в российских soviet studies наконец-то состоялся 5 .

Одной из (если не главной) особенностей «ревизионистского» подхода к советскому является внимание к практикам и технологиям производства субъекта советского модерна. В ходе своего существования эти практики и технологии претерпевали серьезные изменения. Упомянутые выше авторы старались делать основной акцент в своих исследованиях на времени конституирования советской версии Современности, хронологически обычно связываемой с 1920-1930-ми годами, временем индустриализации, коллективизации и построения первого массового общества в крестьянской стране и примыкающими сюда годами войны и послевоенного восстановления (вплоть до 1953 года) ${ }^{6}$. Задача авторов книги «После Сталина» - рассмотреть соответствующие механизмы и практики для последующего времени, которое они ограничивают периодом с 1953 по 1985 год, и, выявив специфические особенности, составляющие их отличие от предшествующей эпохи, понять, что изменилось в советском модерне с завершением эпохи Большого террора, мировых войн и мобилизационного первоначального накопления.

Центральное понятие всего сборника - «субъективность» - вполне справедливо принято связывать с именем Мишеля Фуко. Именно он, в противовес классическому нововременному представлению о субъекте, ввел идею субъективности как набора исторически релятивных, никогда полностью не завершенных практик. Как справедливо указывает в предисловии редактор и составитель сборника Анатолий Пинский, цитируя Фуко, феномен субъективности нужно понимать как «некое поле возможностей, где могут иметь место разнообразные виды руководства, реакций, поведения» (с. 26). Эта идея дает возможность говорить уже не столько о «субъекте» как о законченном носителе смыслов, сколько о «субъективации» как о длящемся во времени процессе, который состоит из множества элементов и проистекает в различных регистрах или режимах. Полемика о правомерности применения этой фукианской оптики к советским исследованиям доста-

3. См. полемику И. Сандомирской с И. Паперно в: Сандомирская И.И. (2012). «Наивное письмо» пятнадцать лет спустя, или На смерть соавтора // Неприкосновенный запас. № 82. С. 206-219.

4. Юрчак A. В. (2014). Это было навсегда, пока не кончилось: последнее советское поколение. М.: Новое литературное обозрение.

5. Хелльбек Й. (2017). Революция от первого лица: дневники сталинской эпохи / Пер. с англ. С. Чачко. М.: Новое литературное обозрение; Хоффман Д. (2017). Взращивание масс: модерное государство и советский социализм. 1914-1939 / Пер. с англ. А. Терещенко. М.: Новое литературное обозрение.

6. Кроме книги А. Юрчака. 
точно полно отражена в предисловии к сборнику (с. 10-12, 26-27). Для описания устройства книги уместно будет вспомнить (хотя бы и в качестве метафоры) о еще одном введенном М. Фуко понятии, обозначаемом им термином «диспозитив» ${ }^{7}$. Так называется механизм или аппарат, состоящий не только из дискурсивных, но и материальных компонентов, чьей задачей является именно та «выделка» субъекта, которую Фуко именует «субъективацией», понимая под ней производство носителей определенных смыслов и ценностей, лежащих в основе того или иного социального порядка. Если (даже сильно упрощая) представить советское общество в виде такого диспозитива, в виде совокупности материальных и дискурсивных практик, длящихся во времени и пространстве, то можно будет с уверенностью сказать, что авторам удалось разобраться если не во всех его частях (это навряд ли возможно в рамках одной конференции и одной книги), то, во всяком случае, во многих из них. Авторы сборника, являясь специалистами в разных областях знания, предлагают мультидисциплинарный подход к исследуемым ими «регионам опыта». Все статьи, так или иначе, представляют собой разбор отдельных конкретных случаев, будь то история студий хорового пения, травелоги советских литераторов или концепции советских урбанистов, поэтому сам формат сборника делает неизбежным краткое изложение его содержания.

Синтия Хупер в статье «Новому советскому человеку случается ошибаться: вместо героических фигур - обыкновенные граждане, неуверенно ищущие счастье» (с. 39-74) утверждает, что послесталинская эпоха, сократившая уровень государственного насилия, привела к расширению того, что можно назвать «пространством личного выбора субъекта», и это расширение непременно должно было найти отражение в современных ей литературе и кинематографе. Предметом ее рассмотрения становятся беллетристика В. Аксенова и киноязык В. Меньшова. Важным критерием новой эпохи, с точки зрения Хупер, выступает сама возможность выбора жизненной траектории. Он может оказаться «ошибочным» или «неправильным», но сам его факт не приводит к распаду субъекта или (что равнозначно) его изгнанию из советского космоса, что было нормой для художественного творчества предшествующей эпохи. Послесталинский субъект получает право на ошибку, последствия которой целиком остаются достоянием его приватной сферы.

В статье «Испытание Сибирью: настоящий человек на великих стройках и в фильмах 1959 года» (с. 108-144) исследователь из Иркутска Михаил Рожанский на материале кинематографа конца 1950-х - начала 1960-х годов отмечает одну важную особенность массовой культуры времен оттепели: внезапное появление Сибири, практически отсутствовавшей в сталинском кинематографе, в смысловом горизонте нового советского субъекта. Автор датирует «сибирский прорыв» в кино 1959 годом (с. 108). По мнению Рожанского, Сибирь начинает играть роль

7. По поводу «диспозитива» см., в частности: Фуко М. (1996). Диспозитив сексуальности // Фуко M. Воля к истине / Пер. с фр. С. Табачниковой. М. С. 175-238; а также: Агамбен Дж. (2012). Что такое диспозитив // Агамбен Дж. Что современно? / Пер. с ит. д. Авг. Соколовски. Киев: Дух и литера. С. 13-44. 
нового советского фронтира (с. 143): теперь это не только мрачное место ссылки и репрессий, но и пространство бесконечной героической экспансии и подчинения природы. Но самое главное, для нового субъекта она становится тем местом, где он встречается с возможностями личностного поиска, персонального выбора и самореализации в повседневной жизни.

Анатолий Пинский в статье «Дневниковая форма и субъективность в хрущевскую эпоху» (с. 145-178) анализирует жанровые смещения, происходившие в послесталинском литературном производстве, и обращает внимание на то значительное место, которое в нем начинает занимать дневниковая проза в сравнении с предшествующей эпохой, когда доминировали большие «легитимные» литературные жанры. Сама по себе дневниковая повествовательная форма не была специфическим изобретением хрущевской Оттепели. Более того, как показали в своих исследованиях Наталия Козлова и Йохен Хелльбек, авторские эгонарративы, дневники и мемуары играли весьма важную роль в складывании персональной идентичности строителей советского модерна. Однако они плохо встраивались в работу существовавшего в тот момент идеологического аппарата, а в какой-то момент даже могли представлять угрозу непосредственному физическому выживанию своего автора. «Легализация» дневников вместе с их эмансипацией в отдельный признанный жанр указывает на происходящую в эпоху Хрущева смену режимов субъективации. Теперь, в условиях ослабления давления, исходящего от партийно-государственных структур, воспитание «сознательности», выражающейся в интересе к эмпирическим фактам существования и способности, буквально по Канту, «пользоваться своим разумом», становится «заботой» самого субъекта.

Появление в послесталинскую эпоху выездного туризма способствует утверждению и расцвету еще одного жанра - путевых заметок. Их влиянию на формирование послесталинского субъекта посвящена статья Ильи Кукулина «Набор очков для изумленного взгляда: конкурирующие образы «советского человека за границей» в литературе оттепели» (с. 179-218). Как правило, авторами советских травелогов выступали представители культурной элиты: дефицитная возможность выезда за рубеж играла роль маркера особого статуса. Травелоги ставят субъекта перед неразрешимым в рамках советского «авторитетного дискурса» противоречием между претендующим на всеобщность официальным идеологическим каноном, носителем которого должен выступать советский турист, и стоящей перед путешествующим автором задачей описания встречи с Другим. Опираясь на литературный материал, автор показывает, как это противоречие ведет к распаду субъекта советских путевых заметок на три различных и плохо соотносящихся друг с другом регистра: агрессивного миссионера, несущего универсальную истину (В. Кочетов), наслаждающегося иностранными историческими пейзажами фланера, пишущего в духе Вальтера Беньямина или Ги Дебора психогеографию своих странствий и лишь изредка вспоминающего о своем всеобщем историческом предназначении (В. Некрасов), а также модного поэта-модерниста, использующего маски знаковых персонажей современной западной поп-культуры, например 
битников или Мэрилин Монро, в качестве перформативной рамки описания актуальных конфликтов и противоречий советской жизни (А. Вознесенский и Е. Евтушенко).

Предметом исследования Алексея Голубева «Западный наблюдатель и западный взгляд в аффективном менеджменте советской субъективности» (с. 219-253) выступает перспектива, в некотором смысле обратная той, что предлагается в тексте Ильи Кукулина: его задача состоит в том, чтобы изучить влияние «западного взгляда» на формирование советского субъекта. Опираясь на идеи Жака Лакана и Луи Альтюссера, автор показывает, что данный взгляд является не столько перспективой реально существующего Другого, сколько необходимым топосом советского политического воображаемого, выполняющим очень важную символическую функцию, без которой невозможна полная самоидентификация советского субъекта.

Бенджамин Натанс в статье «Заговорившие рыбы: о мемуарах советских диссидентов» (с. 398-443) исследует предельный случай позднесоветской субъективации, для которой «западный взгляд» имел критическое значение: диссидентские воспоминания. Он прослеживает происходящее в них постепенное жанровое смещение от агиографий к описанию специфических особенностей соответствующей субкультуры и нравов эпохи. Автор предлагает сопоставить эту трансформацию с происходящими политическими изменениями и отмечает одну важную особенность: между языком диссидентских мемуаров, написанных в советское время, и такими же мемуарами, созданными уже в последующую эпоху, существует впечатляющий разрыв, несводимый к жанровым и стилистическим особенностям анализируемых текстов.

Изменениям, произошедшим в послесталинские годы с сотрудниками советских карательных органов, посвящена работа пермского историка Олега Лейбовича «Работники карательного аппарата в Молотовской области: генезис приватной субъективности 1953-1956» (с. 255-282). Привлекая обширный исторический материал, автор анализирует трансформацию самовосприятия и «отношения к себе» личного состава органов государственной безопасности и внутренних дел одной из областей РСФСР, после ликвидации Л. Берии, разоблачения «культа личности» и фактической их передачи под контроль партии. Лейбович показывает, что даже такие закрытые институты, как милиция и госбезопасность, не остались в стороне от оттепельных процессов гуманизации, индивидуации и расширения персонального пространства, где становится возможен разговор на языке личного достоинства.

Следует заметить, что не все тексты сборника имеют своим предметом только дискурсивные практики формирования нового советского субъекта, находившие свое выражение в литературной или кинематографической жизни той поры. Предметом внимания текста Марии Майофис «Советские мейстерзингеры: движение детских хоровых студий в СССР (1958-1980-е)» (стр. 75-107) становится движение детских хоровых студий, ставшее массовым в послевоенные годы и просущество- 
вавшее вплоть до конца СССР. Некоторые хоровые студии, возникшие в рамках этого движения, функционируют и поныне. Возникнув в порядке добровольной низовой инициативы, ДХС быстро получило поддержку на высоком государственном уровне. Привлекая обширный фактический материал, автор показывает, как массовая эстетическая педагогика стала эффективным инструментом (вос)производства советского субъекта через организацию общности эмоций и аффектов.

Исследованию движения студенческих массовых театров посвящена статья Белль Остромоуховой «Борец с мещанством, бунтарь и весельчак: студенческие эстрадные коллективы 1950-1960-х годов и субъективация схем поведения „советского молодого человека“» (с. 313-351). Движение любительских студенческих театров во многом начиналось как попытка возрождения радикально-модернистских традиций театра первых послереволюционных лет. Однако «пламенный борец за светлое коммунистическое будущее» очень быстро сменяется на сцене отстраненным ироничным КВНщиком. Автор показывает, что попытка искреннего обращения к ценностям учредительного революционного события, на которую изначально опиралось это движение, вела к сдвигам и постепенным трансформациям господствующей идеологии, накапливая в ней критическую сумму изменений.

Материальные элементы «советского диспозитива» рассматриваются в работах Дарьи Бочарниковой и Сьюзан Рейд. Массовое строительство индивидуального жилья - это то, без чего невозможно себе представить послесталинское время. Оно не могло не привести к довольно серьезному переопределению советских представлений о границах личного пространства, о частном и общественном. $\mathrm{Pa}$ бота Дарьи Бочарниковой «Место личности в коммунистическом обществе: разработки группы НЭР на излете политической оттепели» (с. 283-312) посвящена появившейся на закате хрущевской эпохи урбанистической утопии НЭР — «Нового элемента расселения». Она показывает связь идеологии НЭР с раннесоветскими послереволюционными архитектурными утопиями, демонстрируя при этом и существенное ее отличие, связанное в первую очередь с уже радикально изменившимися представлениями о соотношении приватного и публичного. По мнению автора, НЭР представляет собой одну из первых попыток учета меняющихся макросоциальных параметров послевоенного СССР: урбанистического перехода и появления нематериального производства, советской версии «экономики знаний». Концепция НЭР предлагала перестройку градостроительного ландшафта с точки зрения этого намечающегося постиндустриального перехода.

«Освоению» новыми советскими субъектами новых же возникших в это время городских пространств посвящено исследование Сьюзан Рейд «Как обживались в позднесоветской модерности» (с. 352-397). Опираясь на значительный массив интервью и советской lifestyle literature, книг и журналов, описывающих «правильное» использование реалий нового существования, Рейд демонстрирует важное значение, которое имели материальные элементы жизненной инфраструктуры в советской версии консьюмеризма, игравшей значительную роль в формировании позднесоветского субъекта. 
К числу того, что можно было бы назвать небольшими недостатками книги, можно отнести некоторый перекос в сторону литературоведения, в силу чего голос в первую очередь получили привилегированные участники советского модерна, но это, в конце концов, можно объяснить особенностями устройства того «архива», который мы получили в наследство от СССР. Сборник «После Сталина», несомненно, станет вкладом в расширение нашего понимания того, что происходило в СССР после 1953 года, какие процессы (заметные и не очень) вели к накоплению тех важных изменений, что привели к исчезновению советского социального порядка в «два дня». Но это уже вопрос, требующий включения результатов этих штудий в более широкий социально-теоретический горизонт, и он обращен к последующим исследователям.

\title{
The Grammar of Thaw
}

\author{
Maxim Fetisov \\ Candidate of Philosophy, Natalia Kozlova Center for Social Theory and Political Anthropology, Department of \\ Philosophy, Russian State University for the Humanities \\ Address: Miusskaya sq., 6, GSP-3, Moscow, Russian Federation 125993 \\ E-mail:msfetisov@gmail.com
}

Book Review: Anatoly Pinsky (ed.), Posle Stalina: pozdnesovetskaja subjektivnost (1953-1985) [After Stalin: Subjectivity in the Late Soviet Union] (Saint Petersburg: EUSP Press, 2018) (in Russian). 